2-28-2020

\title{
Daijosai and the Separation of Religion and State
}

Thomas Makoto Naruse

Department of Law, Kokushikan University

Follow this and additional works at: https://gensoken.toyo.ac.jp/japanese-society-and-culture

Part of the Constitutional Law Commons, and the Japanese Studies Commons

\section{Recommended Citation}

Naruse, Thomas Makoto (2020) "Daijosai and the Separation of Religion and State," Japanese Society and Culture: Vol. 2 , Article 4.

DOI: $10.52882 / 2434-1738-0204$

Available at: https://gensoken.toyo.ac.jp/japanese-society-and-culture/vol2/iss1/4

This Article is brought to you for free and open access by Institute of Social Sciences. It has been accepted for inclusion in Japanese Society and Culture by an authorized editor of Institute of Social Sciences. 


\section{Daijosai and the Separation of Religion and State}

Thomas Makoto Naruse *

Abstract

Daijosai, which is regarded as an indispensable ceremony for the accession of the throne, is a Shinto ceremony. Therefore, as Japanese Constitution defines separation of church and state, it is not held as a national ceremony (a state act) but held as a ceremony of the imperial house. On the other hand, since it is said to be an indispensable ceremony for the accession of the throne, government finds public significance, and the cost is covered by the national expenses. Criticisms that claim violation of separation of church and state arise, and many lawsuits were filed.

This article reveals that behind the argument of Daijosai and separation of church and state, there are two contexts. On the one side, Japanese Constitution is drafted on the introspection of Meiji Constitution, and restriction of emperor's authority, denial of his deity, abolishing state Shinto, etc. were sought. On the other side, the emperor have been religious and ceremonial being throughout Japanese history, and such existence is deeply rooted both in history and culture. The conflict between these two contexts is inevitable because the constitution maintained the emperor system and at the same time provided for the separation of church and state.

Keywords: Tenno, Japanese Emperor, Accession to the Throne, Sokuinorei, Daijosai, Separation of Religion and State, Japanese Constitution, Shinto Ceremony, National Ceremony (State Act), Ceremony of the Imperial House, National Expense

\section{Introduction}

A change of era from Heisei to Reiwa occurred on May 1, 2019, the next day of Emperor Akihito's abdication. Accession to the Japanese throne is conditioned on the death of the previous emperor since the establishment of the Meiji Constitution. The Imperial House Law had been amended in accordance with the will of the former emperor and succession took place while the former emperor is alive.

Although various works have examined the series of events leading to the former emperor's abdication, this paper deals more generally with the problem of emperor and the principle of the separation of religion and state, that emerges with ceremonies of imperial succession. A number of ceremonies accompany the accession of the throne ${ }^{1}$, among which secular events are performed as national ceremonies (or state acts) and those that involve religion are performed as ceremonies of the imperial house. This distinction reflects the considerations given to the separation of religion and state as stipulated by the Constitution of Japan. Although previous works have critiqued that religious elements have not been entirely dispelled with in state ceremonies, this paper specifically deals with the Daijosai, a Shinto ceremony that is regarded as being essential to the imperial accession. As such, the Daijosai is not a national ceremony but rather a ceremony of the imperial house; however, due to its stated

\footnotetext{
※ Lecturer, Kokushikan University, Department of Law

1 http://www.kunaicho.go.jp/kunaicho/koho/kohyo/pdf/syogishiki-j-e.pdf
} 
indispensability and having an official character, its cost is covered as a national expense. Critiques of violations of separation of religion and state often invoke such cases of spending state funds for religious ceremonies and the participation of public officials in those ceremonies.

In this article, I will examine the issue of the Daijosai and the separation of religion and state. First, I will examine the changes in the basis of the Japanese emperor's position and the being of emperor under the Meiji Constitution versus as under the current Constitution. Next, I will review the drafting process of Article 20 of the Japanese Constitution, which defines the separation of religion and state, and clarify the "purpose" of that clause, following which I will explore the religious aspects of the Daijosai from the government's perspective and describe the process of enacting the Imperial House Law. The latter discussion will include remarks made by then Prince Akishinonomiya that raised doubts about public expenditures for Daijosai based on the principle of the separation of religion and state. Finally, based on the above, I will review some court cases and academic theories concerning the Heisei Daijosai.

\section{Basis of Emperor's Position and its Changes}

(1) Religious Nature of the Emperor

Under the Meiji Constitution, the emperor was described as Arahitogami (a god who appears in the form of a human), and the Constitution stipulated that his person was "sacred and inviolable2". As Professor Lokowandt explains, traditionally, the emperor "was at the center of Shinto ${ }^{3}$," and his existence remains inseparable from that system of beliefs and traditions ${ }^{4}$.

The emperor's status was greatly transformed after the World War II. In the so-called "Imperial Rescript Denying His Divinity (Professing His Humanity)" declared on January 1, 1946, Emperor Hirohito denied his deification ${ }^{5}$. Article 1 of the Japanese Constitution makes the emperor a "symbol of the State and of the unity of the people";"; moreover, his position is derived "from the will of the people.?" This marked a significant change from the previous Constitution, under which his status was based on "deity." With regard to this point, reference is made to the view that it is inevitable that the basis of the emperor's status was transferred to "national sovereignty" because the foundational concept of "the deity" was abandoned 8 .

However, in reality, the emperor continues to be a religious entity even under the current Constitution. There are various Shinto elements in the emperor's life, including ceremonies at the three shrines of the palace and the "imperial regalia" associated with his status. According to Yamamoto, the emperor held 32 ceremonies in 2004, which accounted for $5 \%$ of all of his duties ${ }^{9}$. Thus, even after the World War II, the emperor continues to have religious dimensions. Such religious aspects are often taken up by the Diet, including the crown prince's wedding featuring a Shinto ceremony as a national ceremony

\footnotetext{
2 Dai Nihon Teikoku Kenpo [Constitution] [Meiji Kenpo] art. 1 (Japan)

3 Ernst Lokowandt, The Secular and the Cultic Side of Tenno, in Universality and Peculiarity of the Constitutions in the World 479 (Seibundo 2010).

4 Id. at 478.

5 https://www.ndl.go.jp/constitution/shiryo/03/056shoshi.html

6 Nihonkoku Kenpo [Constitution][Kenpo] art. 1 (Japan).

7 Id.

8 Kudo Tatsuro, Tenno no Koui ha Shukyoteki de Attemo Kamawanaika? —Tenno no <Gishiki> to Seikyo Bunri-, 264 Hogaku Kyoshitu 44, 45 (2002).

9 Yamamoto Masato, Tenno Heika no Zen Shigoto 55 (Kodansha Gendai Shinsho 2009).
} 
as well as the ritual ceremonies of the imperial palace ${ }^{10}$. Although the Togyokurei that stipulated the Shinto ceremonies of Imperial family which enacted under the Meiji Constitution was abolished, a notice issued in May 2, 1947 declares that in cases in which former rules have been abolished and new rules have not yet made, the government should continue to follow earlier precedents ${ }^{11}$. In this way, the style of imperial ceremonies largely follows that of under the Meiji Constitution, thus indicating the continuity of the emperor's religious dimensions.

(2) Characteristics of the Emperor: Institutional Design in the Drafting Process of the Current Constitution

One of the "Hottest" topic during the drafting of the current Constitution following the World War II was making revisions to the political system, particularly reforming those aspects concerning the emperor and placing restrictions on his authority.

As approved by the United States State-War-Navy Coordinating Committee (SWNCC), SWNCC-228 stated that maintaining the imperial system in its previous form did not meet Japan's goal of democratization and would require various changes ${ }^{12}$. Similarly, the General Headquarters (GHQ) report on the so-called Matsumoto Draft strongly criticized that sovereignty remained in the emperor's hands and the national sovereignty required by the 10th section of the Potsdam Declaration had not been enacted ${ }^{13}$

U.S. General Douglas MacArthur favored maintaining the emperor system as a means of avoiding public backlash and facilitating the occupation ${ }^{14}$. As a result, two goals were pursued when drafting the current Constitution: maintaining the emperor system and thorough democratization. In a meeting between the "Steering Committee" and "Committee on the Emperor (original draft)" of the GHQ on February 6, 1946, the emperor's status was drafted as the symbol of the state and the unity of the people ${ }^{15}$, and in the explanatory notes to the constitutional revision, it was stipulated that Japan would "establish a constitutional monarchy with sovereignty re-posing in the people by modifying the Emperor system and making the Emperor the ceremonial head of the state 16 ". This statement also reflects the priority of preventing the emperor's exploitation by evil state leaders, as had occurred in the past ${ }^{17}$. This stance of the GHQ regarding the emperor system was consistent during the entire drafting process.

The meaning of the status of "symbol" and the issue of the "national polity" were frequently discussed during early deliberations at the Imperial Parliament ${ }^{18}$, and the national polity and place of sovereignty were at the center of discussions in both the House of Representatives and the House of Peers ${ }^{19}$.

10 The work on the discussion about the Emperor in Diet, see generally, Ohara Yasuo ed., Shoroku —Koshitu wo Meguru Kokkai Giron (Tendensha 1997).

11 Saito Kenji, Shiryo Shusei Shocho Tennosei (1), 933 Jurist 236, 305 (1989).

12 Takayanagi Kenzo et al. eds., Nihonkoku Kenpo Seitei no Katei —Rengou-koku Sou-Shireibu Gawa no Kiroku ni Yoru I Genbun to Honyaku [The Making of the Constitution of Japan Vol. I Documents] 414-14 (Yuhikaku 1972).

13 Id. at 81-82.

14 Kenpo Kaisei Mondai Shiryoshu Jokan 33 (Watanabe Osamu ed., Junposha 2015).

15 Takayanagi, supra note 12 , at 133.

$16 I d$. at 305.

17 Id. at 308-09.

18 This article pick up some examples. As the work about other discussions, see generally, Shimizu Shin, Chikujo Nihonkoku Kenpo Shingiroku dai 1 kan [1 Clause by Clause Record of Deliberations on Japanese Constitution in Imperial Diet] (Yuhikaku 1962).

19 This article do not step in further. See, Sato Tatsuo, Nihonkou Kenpo Seiritsushi dai 4 kan [4 History of drafting 
Regarding the emperor's status, the government stated that "It is determined that the Emperor should be in the position to represent the nation and embody the unity of the people 20 " so as to eliminate the past mystery and unreality embodied in the position ${ }^{21}$. In addition, to explain the reduction of the emperor's authority, the government stated that "people in power are sometimes invaded by the evil ideas and they distort people's will, indulge the national politics, and implement reckless policy under the name of the Emperor, and finally led the nation to ruin ${ }^{22}$ ". Moreover, during the discussion about the provisions of Article 4 expressed the emperor's role as "reigns, but doesn't govern ${ }^{23}$ " and the "center of admiration" 24 , which reflects the concept of the emperor as a "symbol" 25 . The emperor's ceremonial character was repeatedly reiterated in other documents as well, and the stance of depoliticization and transformation to a ceremonial entity was consistent.

Thus, under the current Constitution, the emperor's status is considered non-political and ceremonial in character. The grounds for the position's existence are not based on the emperor's status as a deity but rather on principle of national sovereignty. In reality, the emperor remains a religious figure; on the other hand, the Constitution also stipulates the separation of religion and state. For this reason, events such as the emperor's religious ceremonies are carried out as "private" acts, and their related costs are expended from inner court expenses, i.e., "private monies". Nonetheless, although such "separation" has been made, there are places where they intersect, the best example of which is the Daijosai. In the next section, I will examine the principle of separation of religion and state before considering the Daijosai.

\section{Separation of Religion and State and State Shinto}

The Japanese Constitution defines the principle of separation of religion and state in Articles 20 and 89, the latter of which is in the chapter on finance clauses. There were two (partly overlapping) purposes for enacting the separation of religion and state clauses in the Constitution of Japan, namely ensuring religious freedom and preventing the restoration of state Shinto. Each objective had previously been expressed in GHQ directives. Article 20 reflects the GHQ's "Removal of Restrictions on Political, Civil and Religious Liberties, ${ }^{26}$ " as well as the guarantee of freedom of religion stated in paragraph 10 of the Potsdam Declaration ${ }^{27}$.

Another GHQ requirement, the so-called "Shinto Directive"28, more vividly reflects Japan's unique circumstances. The beginning of this document states its purpose to "free the Japanese people from direct or indirect compulsion to believe or profess to believe in a religion or cult officially designated by the state, ${ }^{29 "}$ "lift from the Japanese people the burden of compulsory financial support of an ideology

process of Japanese Constitution] 549 (Sato Isao ed., Yuhikaku 1994).

20 Id. at 505.

21 Id.

$22 I d$.

23 Id. at 538.

24 This phrase was often used. As another example, see $I d$. at 561.

25 This point is seen in other parts as well. For some examples, see, Id. at 690-91, and Id. at 857.

26 http://dl.ndl.go.jp/info:ndljp/pid/9885156, http://nirc.nanzan-u.ac.jp/nfile/3229

27 https://www.ndl.go.jp/constitution/etc/j06.html

28 Official title is "Abolition of Governmental Sponsorship, Support, Perpetuation, Control, and Dissemination of Shinto". The text in English is provided websites below: http://nirc.nanzan-u.ac.jp/nfile/3229, http://dl.ndl.go.jp/ info:ndljp/pid/9885515

29 Id. 
which has contributed to their war guilt, defeat, suffering, privation, and present deplorable condition, 30 " prevent "a recurrence of the perversion of Shinto theory and beliefs into militaristic and ultra-nationalistic propaganda designed to delude the Japanese people and lead them into wars of aggression, ${ }^{31}$ " and assist "the Japanese people in a rededication of their national life to building a new Japan based upon ideals of perpetual peace and democracy ${ }^{32}$." Thus, this document reflects the recognition that Shinto was "used" to carry out the war, and based on which concrete measures were mentioned in the below articles of the directive, and conceptions of the directive are reflected in the clauses on separation of religion and state of the Japanese Constitution ${ }^{33}$.

A similar view was expressed in the GHQ's discussions on the drafting of the Constitution. In a meeting between the steering committee and committee on civil rights (original draft), Colonel Roest asserted that "this Article was designed to prevent the abuse of spiritual authority to political ends ${ }^{34}$ " and "Japan has been a priest-ridden country for generations and political tyranny has been reinforced by the threat of spiritual punishment ${ }^{35}$ ". Similarly, the Japanese government explained in the Imperial Parliament that "Traditionally... the government has treated shrines as non-religious beings. According to the spirit of the Potsdam Declaration and with the Directive from the GHQ, shrines have been separated from the nation ${ }^{36}$." The above examples demonstrate the recognition that Shinto was a de facto national religion, and the aim of dealing with state Shinto is strongly reflected in the separation of religion and state clauses of the current Constitution. This background will be referred to when considering the emperor's religious nature.

\section{Religious Character of the Daijosai}

(1) Sokuinorei (Ceremony of the Accession of the Throne) and Daijosai

Ceremony of the accession of the throne (sokuinorei) of the emperor Naruhito was the second one under the current Constitution. The Sokuinorei consists of several national ceremonies and events. As the Imperial Household Office explains:

This is considered as an act in matters of state designated by the Constitution, and consists of Kenji-to-Shokei-no-gi (Accession Ceremony to inherit the Imperial Regalia and the State and Privy Seals), Sokui-go-Choken -no-gi (His Majesty's First Audience Ceremony after the Accession with the Head of the Legislature, Executive, and Judiciary and other Representatives of the people), Sokuirei-Seiden-no-gi (Enthronement Ceremony), Shukuga-Onretsu-no- gi (Imperial Procession by motorcar after the Enthronement Ceremony) and Kyoen-no-gi (Court Banquets) (Designated by the Imperial House Law, Article 24) 37 .

\footnotetext{
$30 \mathrm{Id}$.

$31 \mathrm{Id}$.

$32 I d$.

33 An example of recent work dealing with Shinto Directive and Constitution, Oshima Kayoko, Shusho Kakuryo no Yasukuni Jinja Sanpai no Goukensei, in Takami Katsutoshi Sensei Koki Kinen <Kenpo no Kitei to Kenporon> 237, 237-58 (Shinzansha 2015). An article which criticize the stance that justify the separation of religion and state based on experiences under Meiji Constitution, Annen Junji, Shinkyo no Jiyu, Koza Kenpogaku Dai 3 Kan Kenri no Hosho, 210-11(Higuchi Yoichi ed., Nihon Hyoronsha 1994). A work which questions about the connection between Shinto Directive and Constitution, Ohara Yasuo, Shinto Shirei no Kenkyu 338-39 (Harashobo 1993).

34 Takayanagi, supra note 12, at 201.

$35 \mathrm{Id}$.

36 Shimizu Shin, Chikujo Nihonkoku Kenpo Shingiroku dai 2 kan, 427 [2 Clause by Clause Record of Deliberations on Japanese Constitution in Imperial Diet] (Yuhikaku 1962).

$37 \mathrm{http}$ ///www.kunaicho.go.jp/e-word/word-sokui.html
} 
Criticisms have also been levied against the religious dimensions of Kenjitokeishonogi38; however, those extend beyond this paper's scope, which is focused on the Daijosai.

The Daijosai is not included in the above explanation because it is officially a ceremony of the imperial house rather than a national ceremony. Although the Daijosai was interrupted for about 220 years in the past, it is considered to be indispensable for the accession, and emperor who took the throne without conducting this ceremony was later called a "half-emperor"39. A Shinto religious ceremony, the Daijosai has been variously described as a "Great Ceremony of offering to the Imperial Ancestor and the Deities by the newly-enthroned His Majesty the Emperor ${ }^{40}$ " or a "Great Thanksgiving Ceremony ${ }^{41}$." A similar Shinto ceremony called the Niinamesai is held annually as an observance of the imperial house; however, the Daijosai is a once-in-a-lifetime ceremony that accompanies an emperor's accession of the throne. Well aware of its religious nature, the government explains that "The core of this ceremony is that the Emperor shows gratitude to the ancestors and gods of heaven and earth for public peace and productiveness of grain. For having those purpose and its style, it cannot be denied that it is seen as having a religious character ${ }^{42}$." For that reason, "it is a ceremony that is not suitable for the nation to step into the content ${ }^{43}$, and the government prohibits it to be held as a national ceremony, a state act; rather, it is held as a "ceremony of imperial house."

The Daijosai is positioned as a ceremony that must be performed when the emperor accesses the throne. The government defines the Daijosai as "an once in a throne, extremely important traditional ceremony for succession that accompanies the imperial throne being dynastic ${ }^{44}$, and because the imperial dynasty is defined by the Japanese Constitution, "It is natural that the nation to have deep concern and take measures to enable the ceremony to be held ${ }^{45}$." In other words, the throne's dynasty is defined by the Constitution, and since Daijosai is an indispensable ceremony for the dynasty, it has a great public significance and it is natural for the government to pay the related expenses ${ }^{46}$.

Such discussions have also taken place in the Diet. As the annual Niinamesai is covered by an "inner court expense," or the "private money", there have been questions concerning the difference in treatment ${ }^{47}$. The government determined that whereas the Niinamesai is an annual private event of the imperial family, Daijosai is held once a generation as a traditional ceremony that is indispensable for the imperial accession, which indicates a public significance ${ }^{48}$. In response to questions concerning the meaning of the "public character", the government answered that those which is not purely private, the nation has an interest in it, and appropriate to provide personal or material assistance 49 .

(2) Debate over the Daijosai in the Process of Amending the Imperial House Law

The state's funding of the Daijosai was debated during the process of revising the Imperial House Law

38 The Imperial Regalia are items which are based on Shinto myths, and religiousness has been pointed out.

39 Momochi Akira, Seikyo Bunri Toha Nanika —-Soten no Kaimei— 234-35 (Seibundo 1997).

40 http://www.kunaicho.go.jp/kunaicho/koho/kohyo/pdf/kihonyogo-j-e.pdf

$41 \mathrm{Id}$.

42 https://www.kantei.go.jp/jp/singi/taii_junbi/dai2/sankou1.pdf

43 Id.

44 https://www.kantei.go.jp/jp/singi/taii_junbi/dai2/sankou1.pdf

45 Id.

$46 \mathrm{Id}$.

47 Ohara, supra note 10, at 152.

48 Id. at 152-53.

49 Id. at 153-54. 
after World War II. First, in addressing hypothetical questions and answers regarding the amendment, the Sokuinorei (ceremony of accession of the throne) was considered as a "state act" due to its intimate relationship with the emperor's status as defined in Article 1 of the Constitution ${ }^{50}$. To address issues regarding the separation of religion and state, it was stated that the ceremony's religious overtones would be removed in the future, and the Daijosai and other ceremonies in the Three Shines of the Palace would later be reexamined ${ }^{51}$.

In the parliamentary debate, it was stated that "matters which have religious significance are not received naturally as national ceremonies ${ }^{52}$," and religious elements in the accession ceremonies, including the Daijosai, are not defined in the Imperial House Law ${ }^{53}$. However, this did not mean that none of the Tairei (important imperial ceremonies) would be performed as national ceremonies or state acts. Rather, it was intended to divide the accession ceremonies into two categories: religious and non-religious events. The Imperial House Law would not be involved in the former54; however, this did not herald the abolishment of religious ceremonies ${ }^{55}$. One asked that just as the ban on females becoming emperors and restrictions on marriage to imperial family members are considered "exceptions" to the constitutional provisions of gender equality and freedom of marriage, Daijosai could be treated as an exception to the separation of religion and state ${ }^{56}$. However, the government determined that ceremonies related to religion would be placed outside the system and continue as observances of the imperial family ${ }^{57}$. This stance of defining religious occasions as imperial events is in line with the current government's view.

However, what is noteworthy here is the apportionment of expenses. The government stated that the problem has not yet been deeply considered; however, it would pay the expenses for the national ceremony because it is a state act ${ }^{58}$. The government contended that the Constitution was not directly settled; however, as defined by Article 88, the state's duty to pay the expenses required for the imperial family, therefore state should pay the expenses of religious imperial house ceremonies ${ }^{59}$. In other words, it was determined that the national ceremony (state act) would be paid by the "same national budget as the ordinal national expenses 60 " and the religious imperial house ceremonies would be covered by the government based on Article $88^{61}$. There are some similarities between this stance and that of the current government.

(3) Government's Stance for Daijosai 2019, and Then Prince Akishinonomiya's Remarks

As we have seen above, the Daijosai is covered by public expenses in light of its national significance, despite its religious characteristics and its status as a "ceremony of imperial family". In other words, the

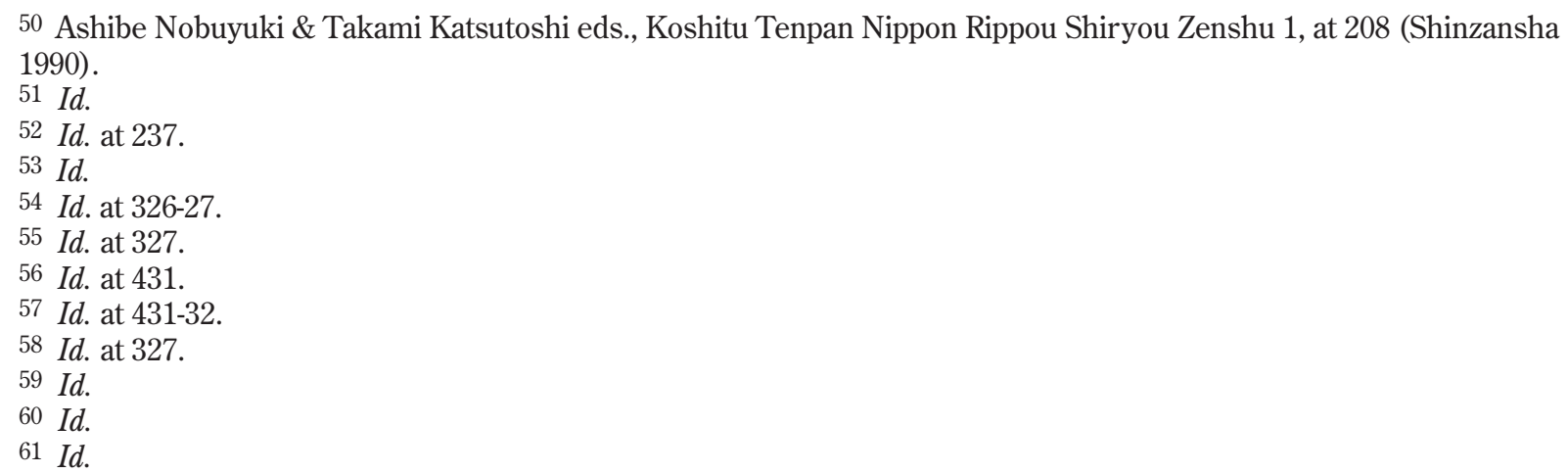


government pays for the Imperial House's "private" and "religious" event due to its public character. The government used the same logic when allocating funding for the 2019 Daijosai, as expressed in a cabinet decision on April 3, 201862. Critics have decried the cabinet decision as a violation of the constitutional separation of religion and state; similarly, then Prince Akishinonomiya expressed a different view than that of the government. When asked about ceremonies and events related to the accession at a press conference held on his 58th birthday in November 30,2018, after acknowledging that the Sokuinorei was a ceremony of the imperial family rather than a national ceremony-so that he could comment on this topic ${ }^{63}$, the Prince stated that he had doubts concerning the appropriateness of spending public money for such events, including the Daijosai of Heisei ${ }^{64}$, and he proposed that the Daijosai should be covered by the private monies i.e. the inner court expense due to his concern for the constitutional principle of the separation of religion and state ${ }^{65}$.

Thus, on the one hand, the government's position is that although the Daijosai cannot be a national ceremony due to the principle of separation of religion and state, it will spend national expenses on the ceremony based on its official character. On the other hand, then Prince Akishinonomiya asserted that the principle of separation of religion and state indicated that public expenditures should not be spent. The cost of the previous Daijosai was estimated to be 2.24 billion yen, and the budget for the Daijosai of 2019 is projected to be 2.71 billion yen ${ }^{66}$. Despite its public character, doubts have been expressed concerning the constitutionality of such expenditures for religious ceremonies, and several lawsuits have been filed. In the following section, I will review some of those lawsuits.

\section{Cases Concerning the Constitutionality of the Daijosai}

An injunction lawsuit based on basic taxpayers' rights was filed against the expenditure of national expenses for the Daijosai scheduled for November 2019; however, the court dismissed it due to the plaintiff's lack of standing ${ }^{67}$. No views were expressed concerning the separation of religion and state in the decision; however, several previous lawsuits filed in various parts of Japan have included constitutional references. There have been two types of lawsuits filed, one of which relates to the constitutionality of the governor's participation in the ceremonies, and the other of which concerns public spending on the Daijosai ${ }^{68}$. This section will review one case of each type.

62 https://www.kantei.go.jp/jp/content/kihonhoushin.pdf

63 https://www.yomiuri.co.jp/national/20181129-OYT1T50081/. Article 4 of Japanese constitution prohibits emperor to act politically, as states "The Emperor shall perform only such acts in matters of state as are provided for in this Constitution and he shall not have powers related to government.” Nihonkoku Kenpo [Constitution] [Kenpo] art.4 (Japan). Accordingly, not only the emperor, but other members of the royal family are also prohibited from interference to the politics, including political speech. Then Prince Akishinonomiya justified his argument against public payment to Daijousai, because Daijousai belongs to the "private sphere of Imperial House". However, authority to making budget bill belongs to the cabinet, and authority to make decision about the budget bill belongs to the Diet (Nihonkoku Kenpo [Constitution][Kenpo] art.86 (Japan).) Therefore, criticism can be made against then Prince Akishinonomiya because he argued against the decision of the cabinet and the Diet about the national budget, which is a highly political matter.

64 https://www.yomiuri.co.jp/national/20181129-OYT1T50081/

$65 I d$.

66 https://www.sankei.com/life/news/181221/lif1812210026-n1.html

67 Tokyo Chihou Saibansho Feb. 5, 2019. Text is available from plaintiff's Website. http://sokudai.zhizhi.net/?p=135

68 For the detailed record of former case especially in the Supreme Court, please see Oguri Minoru, $<$ Shiryou $>$ Daijosai Iken Sosho (8) <Jokokushin-hen Sono 1>: Kagoshimaken Chiji no Daijosai Shusseki ni Tsuiteno Jumin Sosho no Kiroku [<Material> Documents of the Case Daijosai: divine ceremony after the Enthronement (8)], Vol. 35-1 Kagoshima Daigaku Hogaku Ronshu 81-141 (2000). Oguri Minoru, Daijosai Iken Sosho (9) <Jokokushin-hen Sono 2>: 
(1) Supreme Court Decision ${ }^{69}$

A prominent example of the first type of case is the Supreme Court's judgment based on the so-called purpose/effect test in a case filed in Kagoshima. The court affirmed that Daijosai is "the ceremony in which the Emperor shows gratitude to the ancestors and to the gods of heaven and earth for public peace and productiveness of grain. This ceremony was carried out under the Shinto manner at Daijokyu halls where Shinto facilities are installed ${ }^{70}$ " and the governor's attendance and worship represented an entanglement between the state and religion ${ }^{71}$.

However, the judgment also pointed out the public, or secular aspects of the Daijosai, namely that (1) it is an important traditional ceremony regularly held as accession of throne, (2) the governor received an invitation from the Imperial Household Agency and attended and worshipped at Yukidenkyousennnogi (a ceremony which forms a part of Daijosai) with the heads of the three powers, ministers, and representatives of local governments, and (3) the Daijosai is a traditional ceremonial celebration of the symbolic emperor's throne in the traditional ceremonies, and public officials' participation is an appropriate social courtesy ${ }^{72}$. As such, the purpose of the governor's participation was "to perform a social courtesy for the Emperor, which is the symbol of the State and of the unity of the people, as the traditional ceremony of Imperial House accompanied by accession to the throne ${ }^{73}$ " and the effect is not those "aid, assist, encourage, or oppress, or interfere for a specific religion ${ }^{74}$." As such, the court declared that the relationship with religion does not exceed the "allowable limit". Two additional Supreme Court cases involving the accession ceremony also questioned the propriety of public officials' participation; ${ }^{75}$ however, no direct constitutional judgments were made concerning the constitutionality of Daijosai itself.

(2) Decision of the Osaka High Court ${ }^{76}$

In contrast to the above cases, the lawsuit filed in Osaka requested an injunction against public spending on Daijosai, confirmation of its unconstitutionality, and payment of damages against public spending ${ }^{77}$. The court denied standing and dismissed the case; however, it expressed opinions on the Daijosai and separation of religion and state in its dicta.

The court examined each of the Sokuinorei's component ceremonies, stated that the religious nature of the Daijosai was clear, and declared that in light of the purpose/effect test, "at least as an act of assistance, encouragement to state Shinto, the doubt that violation of provision of separation of religion

\footnotetext{
Kagoshimaken Chiji no Daijosai Shusseki ni Tsuiteno Jumin Sosho no Kiroku [Documents of the Case Daijosai: divine ceremony after the Enthronement (9)], Vol. 37-1,2 Kagoshima Daigaku Hogaku Ronshu 3-36 (2003). And for the latter, Soku, Dai Iken Sosho Dan ed. Tenno-sei ni Idonda 1700 Nin (Ryokuhu Shuppan 1995).

691799 Hanrei Jiho 99(Sup. Ct. Jul. 11, 2002). Text is available from the Website of the Courts, and in this article, the page number is based on the website. http://www.courts.go.jp/app/files/hanrei_jp/273/052273_hanrei.pdf at 2.

70 Id.

$71 \mathrm{Id}$.

$72 I d$.

$73 \mathrm{Id}$.

$74 \mathrm{Id}$. at 3 .

75799 Hanrei Jiho 101(Sup. Ct. Jul. 9, 2002), and Sup. Ct. Jun. 28, 2004 (http://www.courts.go.jp/app/files/hanrei_ jp/312/015312_hanrei.pdf).

76 Gyoshu 46.Gyoshu 2,3, 250 (Osaka Kosai Mar. 9, 1995). Text is available from the Website of the Courts, and in this article, the page number is based on the website.(http://www.courts.go.jp/app/files/hanrei_jp/273/052273_ hanrei.pdf).

77 See generally, Id.
} 
and state cannot be denied unconditionally 78 . The court also stated that despite efforts to reduce the religious character comparing to the Sokuinorei under the former Togyokurei and accompanying rules, it still followed those rules in a large part: the Takamikura and the Kusanagi-no-Tsurugi embodying Shinto mythology were used, and it was conducted in relation with the Daijosai and related ceremonies and events; thus, the breaching of the separation of religion and state cannot be unconditionally denied, as was the case for the Daijosai itself ${ }^{79}$. In this case, the plaintiff was defeated because standing was denied; the plaintiff did not appeal, and so the ruling was finalized.

The example presented in the preceding subsection did not discuss whether or not the Daijosai is a violation of the separation of religion and state; however, the court pointed out its secular or ceremonial aspects while also acknowledging its religious nature. However, the latter judgment makes a deeper consideration and raises serious doubts on the constitutionality of Daijosai itself in the light of the separation of religion and state.

\section{View of Academics}

In the section above, I roughly introduced some legal precedents. Below, I will examine academic's theories concerning the constitutionality of Daijosai ${ }^{80}$.

\section{(1) Theory which sees Daijosai Unconstitutional}

In discussing the Kagoshima case, Professor Koizumi criticizes that the Court failed to fully consider the objective situation concerning the purpose of the participation, namely: (1)the strength of the ceremony's religiousness, (2)many public officials did refuse to participate or participated in a private capacity due to concerns regarding violating the principle of separation of religion and state, thus indicating that there were alternative means of conveying congratulations ${ }^{81}$. In addition, regarding the point of the ceremony deriving its public character from the imperial dynasty, Professor Koizumi argues that although the dynasty is a constitutional principle of accession to the throne, this neither requires nor justifies traditional ceremonies, or the tradition does not lessen their religious character ${ }^{82}$. He argues that affirming the public character to the religious ceremonies violates the principle of separation of religion and state.

Professor Tsuchiya agrees that it is a violation of separation of religion and state to make Daijosai a public ceremony (a state act) or to be publicly involved in an official capacity ${ }^{83}$. Under the Meiji Constitution, the Daijosai was inseparable from the Imperial Shinto and the state Shinto under the emperor system by divine right (Shinken Tennosei); however, the basis for it to be held as a national

\footnotetext{
78 Id. at 10.

79 Id.

80 Professor Yokota argues that based on Niinamesai which held every year is paid by inner court expense because of its religious color, stresses the religious character of Daijosai. Yokota Koichi, Kenpo to Tenno-sei 203 (Iwanami Shinsho 1990). Also note, Uemura Sadami, Sokui no Rei Daijosai Iken Sosho Kousoshin Hanketu, 186 Hogaku Kyoshitu Bessatsu Hanrei Select '95, at 10 (1995). Matsumoto Tetsuji, Sokui no Rei Daijosai Iken Jumin Sosho, 234 Hogaku Kyoshitu Bessatsu Hanrei Select '99, at 7 (Yuhikaku 1999). Oguri Minoru, Sokui no Rei Daijosai Iken Sosho Kousoshin Hanketsu, 180 Hogaku Kyoshitu 94 (1995).

81 Koizumi Yoichi, Chiji no Daijosai Sanretsu to Seikyo Bunri Gensoku- Kagoshima Daijosai Sosho Saikosai Hanketsu—, 268 Hogaku Kyoshitu 128, 128 (2003).

82 Id. at 129 .

83 Tsuchiya Hideo, Koui no Keisho, Jurist Zoukan Shin Horitsugaku no Souten Series 3 Kenpo no Soten 48, 49 (Yuhikaku 2008).
} 
ceremony has been lost under the current Constitution, which enforces the denial of the emperor system by divine right ${ }^{84}$. As such, the Daijosai lost public character and is nothing but a mere religious ceremony ${ }^{85}$. Similarly, Professor Mori argues that the ideological devices that supported the emperor system under the Meiji Constitution had been denied and abolished by the conversion of the constitutional principle; thus, making Daijosai publicly held ceremony is equivalent to their resurrection ${ }^{86}$. Professor Kudo also points out that Japan lacks a national religion and the denial of the emperor's deification is a core premise of the current Constitution ${ }^{87}$. Professor Kobayashi agrees that the Daijosai is "a religious ceremony inseparable with the Emperor system by divine rights that was purposefully excluded ${ }^{80}$ " by Japan's defeat in the war and the change of constitutional principle ${ }^{89}$. As such, they conceive that the emperor's religion was abolished from the "public space" by current Constitution.

Strong arguments have been made against the stance of government and the court that finding ceremony of accession of throne public significance and justifies the spending of public money does not distinguish between the "norm" and "reality." For example, Professor Sasagawa argues that the Constitution only defines the Imperial dynasty and its qualifications; thus, the dynasty does not require the Daijosai in the world of norm ${ }^{90}$. Rather, it is the world of reality that makes Daijosai an essential ceremony for the accession of the throne ${ }^{91}$. In this way, he divides the world of norm from the world of reality, and although that the Daijosai belongs solely to the latter (it should be noted that Daijosai is not articulated in any law in Japan), both government and the Court have conflated those two different dimensions ${ }^{92}$. In addition, in his view, the court decision that sees governors' attendance to Daijosai as merely a secular act that "showing respect to the status of symbol" is incorrect because it cannot be derived from the law what kind of attitude should be taken against the "symbol" in the first place; thus, reiterating the ceremony's position in the world of reality ${ }^{93}$. On that basis, the governor should have maintained religious neutrality, and "courtesy" is an inadequate justification for participation in a religious ceremony ${ }^{94}$.

Professor Sasagawa asserts that "The way of succession to the throne must be based on the principle of the national sovereignty, respect for basic human rights, and separation of religion and state in light of the purpose of the Constitution, which is the highest law of the state. ${ }^{95}$ " Professor Kobayashi similarly points out that the Imperial Household Law allows and predicts the performance of ceremony of accession of the throne in accordance with the constitutional order as granted ${ }^{96}$. The religious character

\footnotetext{
$84 I d$.

$85 I d$.

86 Mori Hideki, Daijosai, 123 Hogaku Kyoshitu 6, 7 (1990).

87 Kudo, supra note 8, at 47.

88 Kobayashi Takeshi, Shocho Tenno no Sokui Gishiki to Kenpo-Sokui no Rei Daijosai Iken Sosho Dai Isshin Hanketsu, 152 Hogaku Kyoshitsu 140, 141 (1993).

89 As a similar view, see Kashima Hiroshi, —Sokuirei Daijosai Kokuhi Shishutsu Iken Sosho- Sosho ga Akiraka ni Shitakoto, 316 Hou to Minshushugi 22, 23 (1997).

90 Sasagawa Norikatsu, Rikken Shugi to Tenno Kokumin Shuken to Tenno (1), Koza Kenpogaku Dai 2 Kan Shuken to Kokusai Shakai, 226(Higuchi Yoichi ed., Nihon Hyoronsha 1994). As a similar view, see Mori, supra note 86, at 7.

91 Sasagawa, supra note 90 , at 226.

92 Id. at 228.

$93 \mathrm{Id}$.

94 Id. at 229.

95 Sasagawa Norikatsu, Koi Keisho to Kenpo Mondai, 101 Hogaku Kyoshitu 6, 12 (1989).

96 Kobayashi, supra note 88, at 140.
} 
of emperor is excluded from the public space and is incompatible with the principle of separation of religion and state. As such, spending public money on the Daijosai and the participation of public officials in the ceremony are argued to be unconstitutional.

\section{(2) Theories which see Daijosai as Constitutional}

In contrast to the above scholars, Professor Momochi, citing the view of Professor Ide, emphasizes the emperor's continutiy with the current Constitution and a traditional figure imbued with ceremonial qualities. Professor Momochi's view is that the Constitution establishes a symbolic emperor system (shouchoutennousei); however it does not clearly specify the lineage when defining the imperial dynasty, emperor Hirohito continued to be the emperor as granted, and this can be interpreted as a continuation of the traditional emperor system ${ }^{97}$. Moreover, the Imperial Economic Law stipulates the venerable things that are inherited with the throne; however it does not define exactly what they are, it is interpreted that the "Imperial Regalia" are contained therein ${ }^{98}$. As such, the current Constitution and laws are interpreted based on the traditional figure of the emperor. The emperor as such a traditional existence is defined as a symbol in the current Constitution, based on which he claims that "emperor as symbol in current Constitution $=$ traditional emperor. ${ }^{99 "}$ Thus, Professor Momochi argues that the Constitution affirms the traditional emperor system, and the Daijosai can also be positioned as an public or state ceremony of accession of throne ${ }^{100}$. Based on this tradition, he argues that the Constitution approves the Daijosai ${ }^{101}$.

Based on the above understandings, Professor Momochi discusses the constitutionality of the Daijosai as a public act and as a state act. First, as the separation of religion and state covers the "act of the state or its institution," the public act of the emperor is not considered as an act of national institution; thus, it is not directly applied, and the Constitution will not be violated unless it violates religious neutrality ${ }^{102}$. Even if it is a state act, so long as the Constitution stipulates the imperial dynasty, the indispensable ceremony of the Daijosai is naturally accepted, and it is recognized as an exception to the separation of religion and state along with the issue of the ban on empresses and gender inequality ${ }^{103}$. Even if this is not the case, it will be constitutional in light of the purpose / effect test ${ }^{104}$.

Similarly, Professor Ide suggests that the succession of imperial family is the same as the succession of the emperor's status as symbol ${ }^{105}$. As such, it is unnatural to separate the ceremony of succession of imperial family from the succession ceremony of emperor's status ${ }^{106}$. As he argues, a person becomes emperor based on his succession to the head of the imperial family ${ }^{107}$. Mr. Ide points out that the ceremonies of the imperial house have traditionally been conducted in the Shinto manner, the continuation of which is assumed by the dynasty clause ${ }^{108}$. As such, the Constitution recognizes the emperor's tradition from the front.

97 Momochi, supra note 39, at 250-51.

$98 I d$. at 251.

$99 \mathrm{Id}$.

100 Id.

101 Id. at 249 .

$102 I d$. at 266.

103 Id.

104 Id.

105 Ide Seizo, Tadashii Kenpo Tadashii Kaishaku 75 (Zenponsha 1976).

106 Id.

107 Id.

$108 \mathrm{Id}$. 
(3) Summary

Thus far, we have seen the views of both sides concerning the constitutionality of the Daijosai, which center on the point of whether the emperor and his inseparable religiousness should be excluded from public space (and kept in the private domain) or if we should find value in this tradition and approve public involvement. Professor Sasaki argues that the Constitution positioned the Shrine Shinto outside of the national organization as a result of the dismantling of state Shinto; however, by simultaneously keeping the dynastic emperor as a constitutional organ, and puts emperor Hirohito in that position, the Constitution itself engenders the problem of the monarch's religion ${ }^{109}$. Thus, he highlights the contradictory structure of the Constitution ${ }^{110}$.

In this situation of "contradiction", one side grasps that the Constitution "purposefully excluded" the religious aspect of the emperor. That is, the emperor's divine character and state Shinto were denied and expelled by the conversion to the current Constitution. There is no room for public recognition of these elements under the current Constitution, as they are purposefully excluded, and since the Daijosai is the center of such a ceremony, the principle of separation of religion and state prohibits public involvement. It is recalled that the principle of separation of religion and state originally focused on the exclusion of state Shinto. Here, Professor Sasaki's contention that "understanding of the constitutional structure about how to secure the area of application of modern principle from erosion by premodern remnants is needed ${ }^{111}$ " is noted.

The other side does not perceive that the emperor's religious character has been "excluded" from public space but rather finds value in its "traditional" aspects. The issue of whether the being of the emperor under the current Constitution is continuous or disconnected from that under the previous history (and Meiji Constitution) has been debated; however, they perceive that the current Constitution assumes the emperor's continuity (claiming that the Constitution assumes emperor's traditional aspects) and associates the imperial dynasty with traditional ceremonies. As such, traditional ceremonies-which are imbued with religious aspects-are perceived as being essential to the emperor's being. As the imperial religious ceremonies are inseparable from the emperor's heritage, it is natural that they should be held publicly.

The Japanese Constitution drafted after the World War II reflects the nation's introspection regarding the Meiji Constitution and other "ways of doing" under Meiji Constitution. As such, it inevitably embodies many discontinuities from previous practices. However, it is also true that some issues are not fully addressed during the drafting of the current Constitution. In addition, as Professor Sasaki points out, embedding a religious entity, the emperor in the Constitution engendered tensions in the separation of religion and state. The problem of whether a traditional emperor with religious character is a given in the Constitution or if the "divine" emperor was purposefully excluded lies at the root of the debate over the Daijosai and the separation of religion and state ${ }^{112}$.

109 Sasaki Hiromichi, Sokui no Rei Daijosai to Seikyo Bunri no Gensoku, 217 Bessatsu Jurist Kenpo Hanrei Hyakusen I, at 107 (6th ed. 2013).

$110 I d$.

111 Id.

112 As this problem is quite complicated in nature, more multi-faced consideration is needed. An example of the important work, Sato Koji, Kokuji Koi to Seikyo Bunri, 933 Jurist 101 (1989). 


\section{Conclusion}

As the above discussion highlights, there is tension between the Daijosai and the separation of religion and state. Lawsuits have been filed, judged, and new lawsuits are still pending; thus, this topic is not a thing of the past. Ceremonies of accession of the throne have national significance and are closely related to Article 2 of the Japanese Constitution. However, from the perspective of separation of religion and state, Japan does not have a national religion like the United Kingdom, and denial of the emperor's deification is claimed to be a major constitutional premise ${ }^{113}$. On that basis, many argue that the position of emperor should remain non-religious in public spaces.

As Professor Kudo points out that, like traditional kings, the emperor is a ceremonial being ${ }^{114}$ whose presence is centered on ceremonies. The emperor system has been linked to all forms of government in Japan from ancient times to today, and although there have been changes over time, as Professor Lokowandt emphasizes, the position has always been based on Shinto and the emperor's role of conducting Shinto ceremonies ${ }^{115}$, which are closely related to tradition, culture, and religion. As such, the emperor, the ceremonies, and Shinto are inseparable. Many have advocated separating the private and public spheres of the emperor; however, the distinction between the emperor's public and private is not clear-cut and this makes the problem more complicated.

Professor Sasaki views the problem of the Sokuinorei (ceremony of accession of the throne) and Daijosai - which also evoke the topic of monarch's religion - and separation of religion and state as being inevitable in a constitutional monarchy ${ }^{116}$. He points out that Japan's principle of the separation of religion and state is largely based on those provisions of constitutions of the United States and France, which lack hereditary monarchs ${ }^{117}$, and highlights the need for an interpretation that is distinct from that prevailing in those countries ${ }^{118}$. Although this is an important point, such problems are not unique to Japan. Elements of Christianity appear in various forms in public and political spaces in the United States, including swearing on the Bible during the presidential oath. Although ceremonial deism continues to be debated on many fronts, such frictions related to the separation of religion and state are inevitable as long as the state and political spaces are rooted in society and culture ${ }^{119}$.

The problem of the Dijosai can be grasped on some level as merely another example of broader issues related to the separation of religion and state; however, there is certainly a unique context in the case of Japan. The Constitution of Japan was established after the end of World War II in the context of "introspection" and "correction" of the ways prevailing under the previous Constitution. The separation of religion and state was largely rooted in the aim to revise the relationship between Shinto and state. As to the propositions concerning the emperor system, main interest was in the grounds of the Emperor's status (from deity to national sovereignty), changes in status itself (sovereign to symbol), and the transition of sovereignty (emperor to national). This "context" is placed on one side; however, in addition

\footnotetext{
113 Kudo, supra note 8, at 47.

$114 \mathrm{Id}$. at 46.

115 Lokowandt, supra note 3, at 482.

116 Sasaki Hiromichi, Sokui no Rei Daiosai to Seikyo Bunri no Gensoku, 154 Bessatsu Jurist Kenpo Hanrei Hyakusen I, at $106-07$ ( $4^{\text {th }}$ ed. 2000$)$.

117 Id. at 107.

118 Sasaki, supra note 109, at 107.

119 See generally, Naruse Thomas Makoto, Gireiteki Rishinron ni Tsuite, 28 Hikaku Kenpogaku Kenkyu 129-54 (2016), and articles cited in that article.
} 
to this context of the Constitution, there is also the context of the tradition of the emperor in connection with Japanese history, culture, and society. There has been active discussion on whether the being of the emperor under the current Constitution is continuous or disconnected from that of the emperor under the previous Constitution and of seen in earlier history.

A conflict between these two contexts was inevitable because the Constitution simultaneously maintained the emperor system and provided for the separation of religion and state. The milestone of a new accession to the imperial throne has merely reiterated a longstanding issue. 